\title{
KONSEP TEOLOGI INKLUSIF NURCHOLISH MADJID
}

\author{
Oleh : \\ Dede Ari Sopandi', Mohamad Taofan ${ }^{2}$ \\ Universitas Islam Negeri Sunan Gunung Djati Bandung, \\ STIT Al-Ihsan, Bandung \\ Email: darisopandi32@gmail.com mohamadtofan82@gmail.com
}

\begin{abstract}
Abstrak
Hal yang melatarbelakangi penelitian ini adalah klaim keselamatan dan kebenaran antar kelompok yang menimbulkan perdebatan dan ruang-ruang konflik karena perbedaan, khususnya agama. perpecahan menjadi terbuka lebar dan menyebabkan disharmonis antar kelompok. Ini karena konstruk teologi yang bersifat ekslusif, sehingga implikasinya adalah hilangnya ruang-ruang toleransi. Nurcholish Madjid adalah seorang tokoh yang sangat penting disaat wacana keagamaan di Indonesia dihadapkan pada kondisi yang membingungkan karena keberagaman. Maka dari itu Nurcholish memformulasikan sebuah konsep teologi, yang bertujuan untuk membuka kepada arah persatuan dan perdamaian antar kelompok agama. Dalam kontek ini, penting untuk mengkaji pemikiran Cak Nur, panggilan akrab Nurcholish Madjid, tentang teologi inklusif. Maka dari itu, skripsi ini bertujuan untuk mengetahui argumentasi dasar dan rancang bangun dari pemikiran teologi inklusif Nurcholish Madjid. Nurcholish Madjid memaknai kata inklusif pertama, pandangan kelompok agama lain, pengertian ini sebagai gambaran yang implisit dari kelompok agama tertentu. Kedua, sikap terbuka dan toleran terhadap penganut agama non Muslim. Dari sisi substansi, semua agama itu sama. Kesatuan agama-agama itu terjadi dalam tataran transendental. Hasil temuan dalam penelitian ini, bahwa Nurcholish melihat realitas manusia yang majemuk, dan baginya itu adalah suatu yang niscaya seperti pesan Allah yang tertulis dalam Al-Quran. Ini menurutnya dapat menjadi dasar ke arah pluralisme, yaitu sebuah sistem nilai yang positif terhadap pluralitas. Cak Nur terinspirasi dari Al-Quran dan sejarah Nabi Muhammad, khususnya ketika di Madinah. Madinah ditempati berbagai kelompok manusia yang berbeda-beda, akan tetapi mampu hidup harmonis, terbuka (inklusif) dan saling menghargai. Islam bagi Cak Nur sangat fleksibel, dan dapat didefinisikan ulang. Islam baginya mengandung arti sikap pasrah kepada Tuhan, dan ini menjadi dasar dalam beragama. Karena tidak ada agama yang benar, kecuali sikap pasrah kepada Tuhan. Maka ini menjadi titik pertemuan semua kelompok agama. Sehingga, setiap kelompok agama mampu
\end{abstract}


mewujudkan peradaban yang terbuka (inklusif) dan toleransi, dengan menghayati agama sendiri tanpa menyerang kelompok agama lain.

Kata Kunci: Filsafat Islam, Inklusif, Islam, Pluralisme

\section{Abstract}

The background of this research is the safety and truth claims between groups that lead to debate and spaces of conflict due to differences, especially religion. the split becomes wide open and causes disharmony between groups. This is because the theological construct is exclusive, so the implication is the loss of tolerance spaces. Nurcholish Madjid is a very important figure when religious discourse in Indonesia is faced with confusing conditions because of diversity. Nurcholish formulated a theological concept, which aims to open to the direction of unity and peace between religious groups. In this context, it is important to review Cak Nur's thoughts, Nurcholish Madjid's nickname, about inclusive theology. Therefore, this paper aims to find out the basic and design arguments of the inclusive theological thinking of Nurcholish Madjid. Nurcholish Madjid interpreted the first inclusive word, the view of other religious groups, this understanding as an implicit picture of a particular religious group. Second, an open and tolerant attitude towards adherents of nonMuslim religions. In terms of substance, all religions are the same. The unity of religions takes place at the transcendental level. The findings in this study, that Nurcholish saw a pluralistic human reality, and for him, it was a necessity like the message of Allah written in the Qur'an. This according to him can be the basis for pluralism, namely a system of positive values towards plurality. Cak Nur was inspired by the Koran and the history of the Prophet Muhammad, especially when in Medina. Madinah is occupied by a variety of different groups of people but is able to live in harmony, openness (inclusive), and mutual respect. Islam for Cak Nur is very flexible and can be redefined. Islam for him means to surrender to God, and this becomes the basis of religion. Because there is no true religion, except the attitude of submission to God. So this is the meeting point of all religious groups. Thus, every religious group can realize an open civilization (inclusive) and tolerant, by living its own religion without attacking other religious groups.

Keywords: Islamic Philosophy, Pluralism, Inclusive, Islami, Nurcholis, pluralism 


\section{A. Pendahuluan}

Indonesia merupakan negara yang memiliki keragaman suku dan agama. Pancasila sebagai landasan dalam bernegara, memungkinkan untuk setiap warga negaranya memilih dan melaksanakan ajaran agama yang dianutnya. Ada enam agama yang diakui dan dilindungi oleh Undang-undang Dasar 1945, diantaranya Islam, Katholik, Protestan, Budha, Hindu, dan Kong Hu Chu. ${ }^{1}$ Dengan kondisi masyarakat yang plural, ruang-ruang konflik sangat mungkin terjadi. Dan agama seolah-olah menjadi dasar dari motif kekerasan dikalangan antar umat beragama, karena pemahaman atas doktrin teologis yang destruktif.

Teologi adalah suatu wacana yang di dalamnya berusaha menjelaskan inti iman menggunakan bahasa yang sepadan. Pandangan teologis yang eksklusif beranggapan bahwa kebenaran dan keselamatan hanya terletak pada agamanya sendiri dan tidak terdapat pada agama dan penganut yang lainnya. Dalam sejarah gereja di Barat terdapat ungkapan yang cukup terkenal adalah extra ecclesiam nula salus, yang artinya tidak ada kebenaran di luar gereja. Sikap ini di dukung oleh berbagai ayat pilihan dalam Alkitab yang memang sangat eksklusif.

Teologi eksklusif seperti ini menimbulkan sikap beragama yang kurang toleran dan cenderung kaku terhadap realitas keragaman yang ada. Bom Bali I tahun 2002, tanpa ragu menewaskan 196 jiwa dari 22 negara. ${ }^{2}$ Peristiwa ini merupakan aksi terorisme terburuk sepanjang sejarah di Indonesia. Para pelaku peledakan tersebut berasal dari gerakan radikal islam, dan ini mencoreng perdamaian keagamaan dan rasa kemanusiaan sebagai bangsa dengan pluralitas yang ada, seperti keragaman suku, bahasa, agama, budaya dan keyakinan.

Kejadian ini menjadi pukulan keras bagi umat Muslim di Indonesia yang berupaya menjaga toleransi dan harmonisasi antar kelompok yang ada. Kemudian dari kejadian ini pula menimbulkan citra kekerasan yang seakan menjadi bagian dari keyakinan teologis. Sebagai penganut agama yang

${ }^{1}$ Humas Kemenag, "UU hanya akui 6 agama, kemenag: pemeluk agama lain tetap bisa jalankan ibadahnya,"2013, diakses pada 2 Februari 2018 pukul 20.53 wib, http:/ www.kemendagri.go.id/ news/2013/11/28/ uu-hanya-akui-6-agama- kemenag-pemelukagama-lain-tetap-bisa-jalankan-ibadahnya.

${ }^{2}$ Hendrikus Endar S., Humanisme dan Humaniora (Bandung : Matahari, 2013), 154 
mengedepankan kebenaran dan keselamatan, umat Muslim seharusnya merubah konsepsi dari teologi yang ekslusif ke arah teologi yang lebih inklusif (terbuka).

Masalah inklusivitasini adalah kelanjutan pemikiran dalam Islam dari pemikiran neo-modernisme ke arah yang spesifik sesudah pluralisme, lebih jelasnya pada tataran teologi. ${ }^{3}$ membuka ruang-ruang toleransi, saling berempati dan simpati terhadap kelompok lain. Dalam hal ini, seperti sudah taken for granted kelompok umat beragama yang satu melihat, menilai dan secara sepihak men-judge kelompok agama lain dengan pandangan teologis agama yang dianutnya. Begitupun juga sebaliknya, saling menilai dan menghakimi satu sama lain. Ini menjadi suatu hal yang mustahil untuk membuka ruang toleransi, apalagi sekedar berdialog.

Tidak banyak pemikir Indonesia yang memiliki fokus kajian terhadap masalah pluralitas keagamaan. Nama Nurcholish Madjid adalah salah satu tokoh yang sangat penting ketika wacana tentang keagamaan di Indonesia dihadapkan pada situasi yang membingungkan karena keberagaman. Gagasannya tentang kontekstualisasi ajaran islam, universalisme islam dan pluralisme semakin meneguhkan Cak Nur dengan pemikirannya layak untuk disebut sebagai pioneer. $^{4}$

Salah satu gagasan yang dikemukakan oleh Nurcholish Madjid adalah tentang teologi inklusif, dengan mencari hal yang universal dalam agama. Konsep teologi inklusif Nurcholish berawal dari pemahaman dan pemaknaan terhadap Islam. Pada dasarnya semua risalah samawi adalah Islam. Dalam hal ini, arti umumnya berarti sikap pasrah diri secara sempurna, ataupun sikap tunduk dan patuh terhadap perintah Allah SWT. Adapun Islam dalam arti spesifik lebih kea rah Islam yang diajarkan oleh Nabi Muhammad SAW.

Dalam konteks ke-Indonesiaan yang plural, umat beragama mengalami kebingungan teologis, khusunya bagaimana seseorang harus mendefinisikan dirinya di tengah-tengah agama lain yang juga eksis dan punya keabsahan. Bagaimana pun perilaku pengolok-olokan terhadap

\footnotetext{
${ }^{3}$ Nurcholish Madjid, Islam, Kemodernan dan Keindonesiaan (Bandung: Mizan, 2013), 70

${ }^{4}$ Sunaryo, "Teologi Inklusif Nurcholis Madjid Dan Pengaruhnya Terhadap Fiqh Lintas Agama Di Indonesia.”2
} 
sesembahan dan keercayaan agama lain, maka orang lain pun akan balik menyerangnya. Lahirnya pertikaian dan perpecahan antar umat beragama, saling mengkafirkan satu sama lain, bahkan bisa jadi sampai menimbulkan peperangan antar sesama umat, adalah sebagai konsekuensi logis dari konsepsi teologi yang lebih menekankan pada aspek perbedaan (ekslusif) ketimbang titik persamaan (inklusif).

Maka penting kiranya untuk mewujudkan upaya ke arah terbentuknya konsep Teologi Inklusif yang lebih menekankan pada titik persamaan ketimbang menonjolkan perbedaan, yang dengannya memungkinkan terciptanya perilaku saling memahami, menghargai menghormati keyakinan intra dan antar umat beragama. Terciptanya ruang dialog satu sama lainnya dan memungkinkan terjadinya kerjasama antar umat beragama dalam mengatasi problem-problem kemanusiaan sehingga agama menjadi kekuatan (problem solver) dalam kehidupan manusia.

Jatuhnya pilihan penulis pada pemikiran teologi Inklusif Cak Nur didasarkan pada pertimbangan bahwa Cak Nur berbeda dari main stream memahami kata "Islam" dalam Al-Qur'an Surat Al-Imran ayat 19 :

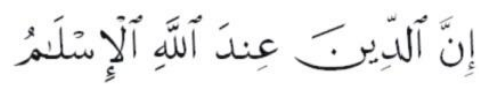

Kata Islam dalam ayat tersebut tidak dipahami dengan Islam sebagai komunitas atau organisasi, tetapi lebih kepada Islam sebagai perilaku yang sepenuhnya menyandarkan diri hanya kepada Allah SWT. Kemudian Nurcholish Madjid menyebutnya dengan "keberagamaan yang benar, “ seperti dalam Al-Qur'an yang merupakan keberagamaannya para Nabi dan Rasul mulai dari Adam AS sampai Nabi Muhammad SAW. Dengan ungkapan lain bahwa Islam sebagai sikap keberagamaan yang tunduk, patuh, taat dan berserah diri pada Tuhan.

\section{B. Hasil dan Pembahan}

\section{Argumentasi Filosofis Teologi Inklusif Nurcholish Madjid}

Tiga tema pokok dalam pemikiran Cak Nur adalah mengenai keislaman, keindonesiaan dan kemodernan. Menurut Budhy Munawar, Cak Nur adalah seorang pluralis, akan tetapi ia tidak seperti kebanyakan 
tokoh pluralis lain. Cak Nur menjauhkan diri dari tiga poin yakni tidak ada keunikan dalam agama, semua agama sama saja, bisa dicampur aduk. ${ }^{5}$

Islam artinya berserah diri sepenuhnya hanya kepada Allah, Islam adalah pokok dari semua ajaran agama yang benar. Nabi Nuh dan Ibrahim juga mengajarkan Islam. Seperti yang penulis kutip dari Cak Nur, Seorang tokoh klasik Ibnu Taymiyyah menyatakan dalamIqtidla al-Shirath al-Mustaqim bahwa para Nabi hanya membawa satu agama, yakni Islam (berserah diri) kepada Allah. Akan tetapi ada perbedaan karena perbedaan zaman serta tempat para Nabi itu diutus. ${ }^{6}$

Sebagai sebuah agama, Islam memiliki makna iman, kebaikan, dan menghindari kesalahan. Disini dapat kita lihat, bahwa nilai Islam adalah untuk semua umat. Dalam pandangan Osman Bakar, orang yang berislam adalah kesaksian iman kepada Allah (la ilah illa Allah). ${ }^{7}$ Kesimpulan dari kesadaran ketuhanan adalah lahirnya sifat taqwa kepada Allah SWT. Dalam pandangan Cak Nur, manusia berasal dari Tuhan dan pasti kembali kepada Tuhan. ${ }^{8}$

Islam dalam hakikatnya tidak lepas dari agama (Ad-Din), sesuai dengan firman Allah dalam Al-Quran: "tidak ada agama (al-Din) yang benar tanpa kepasrahan kepada Tuhan (al-Islam)". Wilfred seperti yang dikutip Nurcholish mengemukakan bahwa Islam merupakan sebuah ajaran-ajaran, kemudian ajaran-ajaran itu diterima oleh Nabi Muhammad SAW, ${ }^{9}$ dalam kata lain berarti Islam bukan sekedar nama agama.

Dalam pandangan Nurcholish Madjid, Islam sebagai nama agama mempunyai nilai-nilai universal. ini berhubungan erat dengan fungsi $\mathrm{Al}$ Qur'an dan Hadist, juga realitas yang melingkupinya. ${ }^{10}$ Secara lebih dalam, Al-Qur'an tidak mengatur secara rinci dan Hadist merupakan penjelasan yang tidak lain adalah pemahaman Nabi atas isi dari Al-Qur'an, agar

\footnotetext{
${ }^{5}$ Budhy Munawwar Rachman, Titik Temu Agama-Agama, Analisis Atas (Jakarta: Sekolah Tinggi Filsafat Driyarkara 2014), 23-24

${ }^{6}$ Nurcholish Madjid, Pintu-pintu Menuju Tuhan, 2

${ }^{7}$ Osman Bakar, Tauhid dan Sains (Bandung : Pustaka Hidayah, 2008), 67

${ }^{8}$ Nurcholish Madjid, Islam, Doktrin dan Peradaban, xv

${ }^{9}$ Harun Nasution, Islam di Tinjau dari Beberapa Aspek (Jakarta : UI Press, 1985), 17

10 Budhy Munawar Rachman, Konteks Doktrin Islam dalam Sejarah (Jakarta : Paramadina, 2010), 210
} 
mendapat pemahaman tentang isi Al-Quran dapat diterima manusia. Jamez Kritzack dalam Anthology of Islamic Literature yang penulis kutip dari Nurcholish menyatakan Al-Qur'an bagi orang Muslim, merupakan kalam Allah yang nilainya transendental. Maka dari itu, menurut pandangan ulama klasik, Al-Qur'an merupakan bacaan yang suci dalam bahasa asli, tidak dalam terjemahannya. ${ }^{11}$

\section{Pluralisme Agama}

Konsep teologi inklusif membuka jalan terhadap kesadaran tentang adanya nilai kebenaran dalam syariat yang berbeda. Konsep teologi inklusif adalah sumbangsih yang luar biasa dari pemikiranseorang Nurcholish Madjid, agar terbentuknya masyarakat sejahtera. Teologi ini dibangun dengan melihat realitas umat Islam yang ada di Indonesia, dan juga adanya sikap apokaliptisisme. ${ }^{12}$ Sikap ini menjangkit beberapa kelompok agama Islam, Kriten, Yahudi dan lainnya di seluruh dunia. Ini merupakan sikap beragama dengan membenarkan aksi kekerasan, atas nama agama. Dasardasar dari konsep teologi inklusif Nurcholish adalah sebagai berikut:

Konsep Ajaran Tauhid, dalam konsep ini Cak Nur mengarahkan untuk mengeksplorasi dasar-dasar pemahaman ajaran-ajaran dari Islam, Kristen dan Yahudi yang mempertemukan sisi kesamaan antara ketiga agama tersebut, terutama pada konsep tradisi monoteisme Ibrahim. ${ }^{13}$ Pemikiran Cak Nur tersebut merupakan pandangan positif pluralisme agama. Pandangan ini menjelaskan bahwa pluralitas atau kemajemukan umat manusiamerupakan sebuah kenyataan yang harus diterima karena telah menjadi kehendak Allah. Hal ini diperkuat oleh dalil Al-Qur'an yang menyatakan bahwa manusia itu diciptakan berbangsa-bangsa dan bersuku-

\footnotetext{
${ }^{11}$ Nurcholish Madjid, Khazanah Intelektual Islam, 82

${ }_{12}$ Apokaliptisisme adalah pandangang sekelompok penganut agama bahwa dunia sekarang berada dalam peperangan dimana kekuatan-kekuatan yang bermusuhan, kekuatan kebaikan dan kejahatan, kekuatan Tuhan dan setan, tengah saling bertempur. Sebagai umat beragama mereka terpanggil untuk mengambil bagian dalam perang itu. Mereka memandang diri sebagai tentara Tuhan yang harus menghancurkan para pengikut pasukan setan. Lihat Robert Setio, Kekerasan dalam Akopakiptisisme, dalam Alef Theria, dkk (ed), Harmonisasi Kehidupan Beragama: Problem, Praktik dan Pendidikan (Yogyakarta : Oasis Publisher, 2005), 204-205

13 Lihat QS. Ali-Imran : 65-68.
} 
suku agar mereka saling kenal dan menghargai. ${ }^{14}$ Dari ayat inilah sikap toleransi harus ditumbuhkan, yakni sistem nilai yang secara positif optimis terhadap kemajemukan itu sendiri dengan menerimanya sebagai kenyataan dan berbuat sebaik mungkin berdasar kenyataan. ${ }^{15}$

Al-Quran sebagai pokok pegangan umat Islam telah menjelaskan bahwa baik Nabi Muhammad SAW maupun para Nabi yang lebih awal diutus Allah SWT, ditugaskan untuk menyampaikan pesan taqwa kepada Allah SWT. Hal ini tercantum dalam Q.S An-Nisa :131. ${ }^{16}$ Seperti yang dikemukakan oleh Budhy Munawwar Rachman:

...Takwa, menyangkut hubungan antara manusia dengan Tuhan.Tetapi implikasi dari takwa bersifat kemanusiaan. Apabila orang bertakwa kepada Tuhan, maka implikasinya adalah bersikap adil terhadap sesama manusia.Sikap takwa juga menyelamatkan manusia dari kekerdilan jiwa.Nabi Musa diperintah menjaga dirinya, dengan bertakwa kepada Tuhan, sehingga tuhan menjaganya dari rencana buruk yang dibuat oleh Fir'un. Takwa adalah dasar dari hubungan antara laki-laki dan perempuan dalam membentuk keluarga (Qs. 4;1).

“...Takwa di satu pihak dalam pengertiannya juga mencakup iman kepada Allah, hari akhir, para malaikat, kitab-kitab dan para pendahulu.....

Takwa adalah sebuah dasar kemanusiaan. Takwa, menyatakan seluruh kemanusiaan, hal ini dapat terlihat dengan jelas secara historis.Umpanya bangsa Yahudi pernah mengklaim, bahwa dirinya sebagai bangsa kekasih Tuhan.Dan sekarang, masih terlihat dengan jelas, bahwa masih ada sebuah kelompok atau sekumpulan manusia yang merasa dirinya paling unggul dan paling benar dari pada bangsa yang lainnya. Namun dibantah oleh al-Qur'an Q.S. 49:13. ${ }^{17}$ Ayat ini menegaskan bahwa kriteria kemuliaan di hadapan Allah itu hanyalah taqwa kepada-Nya terlepas dari perbedaan bangsa, ras, suku, individu, suatu kriteria yang dapat membuat

${ }^{14}$ QS. Al-Hujarat : 13.

15 Nurcholish Madjid, Islam Doktrin dan Peradaban, ixxv

16“....Dan sesungguhnya telah kami perintahkan kepada mereka ahli kitab sebelum kamu, juga kepada kamu, supaya bertaqwa kepada Allah...."

17"Kami menciptkan kamu dari pria dan wanita, dan membuat kamu bersuku-suku dan berbangsa-bangsa, agar kamu saling mengenal. Sesungguhnya sesungguhnya orang yang paling muliaa disisi Allah adalah orang yang bertakwa di antara kamu” 
hidup lebih dinamis, karena di sini orang berlomba-lomba dalam kebaikan. $^{18}$

Dari kutipan di atas dapat disimpulkan bahwa sifat takwa hanya bisa dicapai melalui jalan Iman kepada Allah SWT. Dalam pandangan Nurcholish, taqwa merupakan sikap takut kepada Tuhan, dalam hal ini sikap menjaga dari diri dari perbuatan jahat serta menjauhkan diri dari larangan Tuhan. Seperti yang penulis kutip dari Budhy Munawar Rachman, Nurcholish mengutip Mohamad Asad dalam the Message of the Al-Quran, menterjemahkan kata taqwa sebagai God consciousness (kesadaran Rabbaniyyah). Diutusnya para Nabi dan Rasul adalah untuk mencapai kesadaran Rabbaniyyah dan sekaligus sikap dan kesediaan menyesuaikan diri di bawah cahaya kesadaran Ketuhanan tersebut. ${ }^{19}$

\section{a. Keadilan}

Hampir setiap kelompok agama memandang perjalanan masa lalu dalam gambar ideal. Akan tetapi, yang membedakan orang Islam dengan penganut agama lain adalah bahwa orang Islam modern bisa memandang luas dukungan kenyataan historis untuk kemudian melihat masa lampau yang dalam pandangan Nurcholish disebut juga dengan salaf (klasik), atau al-Salaf al-Shalih (Klasik yang saleh) pada masa selain zaman nabi Muhammad SAW masa para sahabat Nabi dan Tabiun (para pengikut Nabi). ${ }^{20}$

Keadilan berhubungan dengan ihsan, yakni sikap untuk melakukan kebaikan secara tulus. Menurut Nurcholish, adil (adl) merupakan bentuk seimbang semangat modernisasi dan toleransi. Menurut beberapa teolog Islam juga dikenal dengan istilah (wasath).

Adl secara harfiah, merupakan kata benda abstrak dari kata kerja adala. Pertama, meluruskan, mengubah. Kedua, lari dari jalan keliru ke jalan

\footnotetext{
${ }^{18}$ Budhy Munawwar Rachman, Membaca Nurcholish Madjid, 53-54, lihat, Dawan Rhardjo, Ensiklopedi al-Quran: Tafsir Sosial Berdasarkan Konsep-konsep Kunci (Jakarta: Paramadina, 1996), 165-167

${ }^{19}$ Budhy Munawwar Rachman, Membaca Nurcholish Madjid, 55

${ }^{20}$ Budhy Munawar Rachman, Membaca Nurcholish Madjid, 185
} 
yang benar. Ketiga, sepadan. Keempat, menyeimbangkan. ${ }^{21}$ Di dalam AlQuran Surat An-Nisa: 123-124, ${ }^{22}$ menjelaskan bahwa Allah SWT tidak mendiskriminasi. Tuhan akan berlaku objektif, untuk yang berbuat kebaikan diberikannya ganjaran, dan untuk yang berlaku jahat maka akan mendapat ganjarannya pula sesuai denga apa yang dikerjakannya. ${ }^{23}$

\section{b. Iman}

Dalam konteks kehidupan sehari-hari, sering kita mendengar kata iman, islam, ihsan, tawakal, ikhlas dan juga taqwa. Semuanya menunjukan poin penting sebagai pertanda kualitas diri sebagai hamba kepada Tuhan. Karena itu adalah kesimpulan iman kepada Tuhan yang Maha Esa. Dalam konteks ini Nurcholish menegaskan:

Iman (iman) sering diartikan sebagai percaya. Pengertian ini belum komprehensif dan menyeluruh. Untuk mengetahui kata Iman, maka yang harus dilakukan adalah menelusuri semua kosa kata ini dalam Al-Qur'an. Kata Iman berasal dari amana (aman) yang berarti kesejahteraan/sentausa dan amanat (amanah) yakni keadaan bisa dipercaya atau diandalkan (trust worthiness). Kata Iman merupakan lawan dari kata khianat. ${ }^{24}$

Maka berilah kabar gembira kepada hamba-hamba-Ku. Yaitu mereka yang mendengarkan perkataan kemudian mengikuti mana yang terbaik.Mereka itulah orang-orang yang diberi petunjuk oleh Allah, dan mereka itulah orang-orang yang berakal budi. ${ }^{25}$

Orang yang beriman, akan mendapatkan hidayah dari Tuhan, yaitu dengan cara mendengar perkataan (al-qawl), seperti pendapat Al-Razi dan juga Al-Thabari yang dikutip dari Nurcholish, firman-firman Allah dan juga sabda para Nabi dan Rasul, pendapat sesama manusia, lalu memahami dan

\footnotetext{
${ }^{21}$ Budhy Munawar Rachman, Islam dan Liberalisme, 71

${ }^{22}$ Ganjaran Tuhan itu bukan angan-angan kosongmu, dan pula tidak menurut anganangan ahli kitab. Barangsiapa yang mengerjakan kebajikan, baik laki-laki atau perempuan dari kalangan orang yang beriman, maka mereakan masuk ke dalam surgadan mereka tidak akan dizalimi (diperlakukan secara tidak adil) sedikitpun.

${ }^{23}$ Zuhairi Misrawi, Doktrin Islam Progresif, 47

${ }^{24}$ Nurcholish Madjid, Islam, Doktrin dan Peradaban, 94

${ }^{25}$ Al-Quran Surat Azzumar : 17
} 
ikuti yang baik. ${ }^{26}$ Perumpamaannya adalah manusia harus melihat ke atas, sebagai melihat Tuhan atau hubungannya dengan Tuhan. Melihat lurus sebagai hubungan dengan sesama manusia, dan juga melihat ke bawah sebagai hubungannya dengan alam. Sebab, hanya dengan cara itulah kita sebagai manusia akan menemukan jati dirinya, atau manusia akan deutuhnya memusatkan seluruh kegiatannya dan perhatiannya kepada Tuhan.

Dari sini menurut pendapat Nurcholish, manusia akan bertemu dengan dengan makna iman. Dengan hanya menjadikan Allah SWT sebagai arah dan tujuan segala perbuatan hidupnya di dunia, atau berbuat sesuatu demi ridho Tuhan. ${ }^{27}$

Sedangkan maksud dari sikap terbuka, adalah mengetahui bahwa mustahil, manusia mengetahui seluruh kebenaran. Dalam pandangan Nurcholish, manusia yang mengenali dirinya sendiri, maka ia akan mengenal Tuhannya. Munculnya kesadaran bahwa dirinya memiliki keterbatasan, merupakan implikasi dari keyakinan bahwa hanya Tuhanlah yang Maha sempurna. ${ }^{28}$

\section{Rancang Bangun Pemikiran Teologi Inklusif Nurcholish Madjid}

Gagasan utama Cak Nur membangun teologi inklusif adalah penekanan pemahaman terhadap pesan Tuhan dalam semua kitab (Zabur, Taurat, Injil dan Al-Quran), diantaranya adalah pesan taqwa. Lebih jauh lagi, sebagaimana Al-Quran memerintahkan untuk menjaga perasaan orangorang Musrik, dengan menghormati dan melarang untuk menistakan sesembahannya. Seperti firman Allah SWT dalam Al-Quran ::

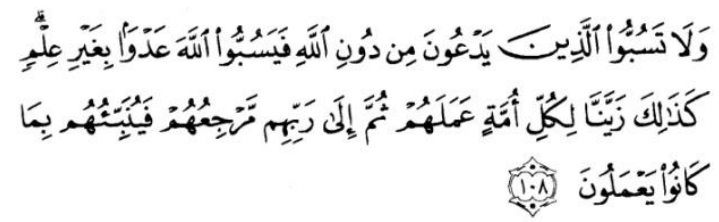

Dan Janganlah kamu memaki sembahan-sembahan yang mereka sembah selain Allah dengan melampaui batas tanpa dasar pengetahuan.

\footnotetext{
${ }^{26}$ Nurcholish Madjid, Pintu-pintu Menuju Tuhan, 10

${ }^{27}$ Nurcholish Madjid, Islam, Doktrin dan Peradaban, 97-98

${ }^{28}$ Nurcholish Madjid, Pintu-pintu Menuju Tuhan, 11
} 
Demikianlah, kami jadikan setiap umat menganggap baik pekerjaan mereka. Kemudian kepada Tuhan tempat kembali mereka, lalu dia akan memberitahukan kepada mereka apa yang telah mereka kerjakan. (Q.S. AlAn'am : 108)

Teologi Inklusif dapat disebut sebagai teologi perdamaian atau teologi kerukunan beragama. Inklusifisme keberagamanadalah sikap terbuka dan saling menghargai segala bentuk perbedaan. Sebaliknya, sikap ekslusifisme akan menimbulkan kecenderungan untuk pertikaian dan ketidaktentraman masyarakat. Maka dari itu perlunya membangun bersama sikap inklusif.

Agama merupakan system kepercayaan yang tidak boleh dijadikan sebagai pembatas untuk berinteraksi dengan sesame manusia. Pentingnya kerukunan agar terwujudnya kesatuan pandangan untuk selanjutnya menciptakan kesatuan tindakan dan perbuatan. Dalam pandangan Cak Nur, iman membangun kesadaran mengemban amanat ilahi, kesadaran sebagai sesame mahluk akan menciptakan rasa saling menghargai, saling mengigatkan dalam kebaikan dan kebenaran tetntunya tanpa memaksakan pendapat sendiri. ${ }^{29}$ Dengan sikap inilah kemudian memperlihatkan kualitas budi dan kemuliaan seseorang.

Teologi inklusif beupaya membangun kesadaran dan pengakuan bahwa ada kebenaran dalam setiap syariat yang berbeda, dan perbedaan merupakan sebua keniscayaan yang berasal dari Tuhan.

\section{Sumber Inspirasi}

Teologi Inklusif yang dibangun oleh Nurcholish Madjid mendapat sumber inspirasinya dari Kitab Suci dan sejarah Nabi Muhammad SAW. Cak Nur hendak menunjukan bahwa Islam mempunyai ajaran-ajaran dinamis yang tentunya bisa dipergunakan sebagai sumber referensi untuk mengkonstruksi teologi inklusif.

Nurcholish dalam beberapa tulisannya memperlihatkan kondisi Madinah era Nabi Muhammad SAW. Pada saat pertama Nabi datang ke

\footnotetext{
${ }^{29}$ Nurcholis Madjid, Islam, Doktrin dan Peradaban, 126
} 
Madinah, kelompok Muslim adalah minoritas. Akan tetapi, hal tersebut tidak menjadi halangan untuk membangun sebuah peradaban yang menjungjung tinggi persamaan, kesetaraan, keadilan, dan peradaban. ${ }^{30}$ Persoalannya adalah bukan tentang mayoritas dan minoritas, akan tetapi lebih jauh dari pada itu, yaitu sebuah komitmen bersama untuk memulai hidup yang baru dengan menjunjung tinggi harmoni dan toleransi. Nurcholish Madjid menjelaskan:

.... Suatu kenyataan bahwa seluruh dunia Islam, kecuali kompleks Tanah Suci Makkah yang penting. Kaum minoritas itu merupakan bukti hidup tentang adanya keterbukaan, sikap saling menghargai, dan toleransi orangorang Muslim sejak zaman klasik sampai sekarang. Orang-orang Muslim, sebagaimana tampak jelas dari ajaran agamanya (yang murni), adalah pengemban tugas sebagai "mediator" atau penengah (wasith : wasit) antara berbagai kelompok umat manusia, dan diharapkan untuk menjadi saksi yang adil dan fair dalam hubungan antar kelompok itu. Inilah yang mendorong kaum Muslim klasik bersikap demikian terbuka dan inklusif, sehingga dalam bertindak selaku pemegang kekuasaan mereka bersikap "ngemong" ${ }^{31}$ terhadap golongan-golongan lain. ${ }^{32}$

Menurut Zuhairi, pandangan Cak Nur bahwa Madinah harus menjadi sumber inspirasi untuk membentuk masyarakat modern yang dapat menjunjung tinggi kebhinekaan, adalah benar. ${ }^{33}$ Pernyataan ini juga dipertegas oleh Nurcholish sebagai berikut:

Pluralisme Madinah di bawah pimpinan Rasulullah SAW dan berdasarkan konstitusinya itu berjalan secara baik dan lancar, dengan tiaptiap kelompok mengambil bagian kegiatan sesuai dengan tugas dan kewajibannya masing-masing, termasuk pertahanan terhadap musuh dari luar, sampai dengan terjadinya penghianatan demi penghianatan yang fatal oleh beberapa kelompok orang-orang Yahudi Madinah penandatangan konstitusi. Karena penghianatan itu sangat

\footnotetext{
${ }^{30}$ Zuhairi Misrawi, Madinah : Kota Suci, Piagam Madinah dan Teladan Muhammad SAW (Jakarta : PT Kompas Media Nusantara, 2009), 72

31 "ngemong" berasal dari bahasa Jawa yang merupakan kata sifat yang artinya memelihara.

${ }^{32}$ Nurcholish Madjid, Islam, Doktrin dan Peradaban, 308-309

${ }^{33}$ Zuhairi Misrawi, Madinah : Kota Suci, Piagam Madinah dan Teladan Muhammad SAW, 72
} 
membahayakan tatanan sosial yang sedang dibangun, maka pelakunya mendapat hukuman setimpal....

Maka sejak saat itu masyarakat politik Madinah berkembang ke arah yang lebih homogen. ${ }^{34}$ Jika melihat Negara Indonesia, yang beraneka ragam suku, ras, dan agama, sekilas mirip dengan Madinah era Nabi Muhammad SAW. Indonesia mempunyai ideologi Pancasila sebagai dasar dalam bernegara, dan sebagai lambang persatuan semua kelompok yang ada. Seluruh rakyat Indonesia dilindungi dan dijamin keberadaannya, selama ia mentaati aturan yang tertulis dalam UUD 1945 sebagai hukum tertinggi. hal ini dipertegas oleh Nurcholish sebagai berikut:

... Saya pernah membandingkan Pancasila dengan konstitusi Madinah, sebab sama-sama berlaku sebagai Common Platform, sebagai titik pertemuan diantara kelomok-kelompok yang ada. Waktu itu Nabi mencoba mempersatukan masyarakat Islam, Yahudi, dan orang lain yang disebut belum Islam. Dan dengan konstitusi ini lalu terciptalah yang disebut umat yang satu. Sebab itu upaya mencari titik persatuanlah yang harus dipersoalkan. ${ }^{35}$

Islam sebenarnya adalah agama yang sangat inklusif dan mengakui keberadaan dari kelompok agama lain. Hal ini terlihat dari ajaran-ajarannya yang termaktub dalam Al-Qur'an. Sikap terbuka dan mengakui eksistensi kelompok lain menjadi aspek penting dalam membangun sebuah peradaban yang harmonis dan saling menghargai. Sebagaimana dijelaskan oleh Nurcholish, bahwa sikap ini sudah dicontohkan oleh Nabi Muhammad SAW ketika beliau berada di Madinah. Hal pertama yang dilakukannya adalah pengakuan atas hak eksistensi masing-masing kelompok di Madinah yang plural. Semua dokumen ini termaktub dalam "konstitusi Madinah."

Madinah dalam perjalannya, menjadi kota yang berperadaban unggul dengan bangunan toleransi di bawah pimpinan Nabi Muhammad

\footnotetext{
${ }^{34}$ Nurcholish Madjid, Cita-cita Politik Islam, 39

${ }^{35}$ Nurcholish Madjid, Dialog Keterbukaan, 127

${ }^{36}$ Nurcholis Madjid, Islam Doktrin dan Peradaban, 68
} 
SAW. Sebagai seorang seorang Rasul sekaligus pimpinan Negara, Nabi Muhammad memberikan kebebasan terhadap para ahli kitab untuk memeluk agamanya. Bahkan beliau melarang para sahabatnya untuk memerangi dan menyakiti mereka. Hal ini juga dijelaskan dalam Q.S. AlBaqarah ayat 256 :

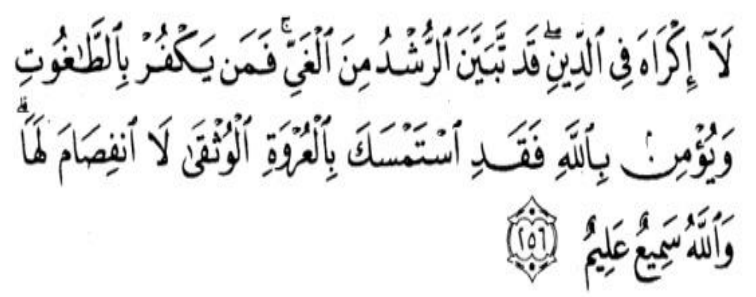

Tidak ada paksaan dalam (menganut) agama (Islam), sesungguhnya telah jelas (perbedaan) antara jalan yang benar dengan jalan yang sesat. Barang siapa yang ingkar kepada Tagut dan beriman kepada Allah, maka sungguh, dia telah berpegang (teguh) pada tali yang sangat kuat yang tidak akan putus. Allah Maha mendengar, Maha mengetahui. (Q.S Al- Baqarah: 256). ${ }^{37}$

Islam di bawah pimpinan Nabi Muhammad SAW di Madinah, memberikan contoh toleransi yang sangat komplit. Ajaran itu kemudian menjadi wordview Islam bagaimana membangun peradabannya di tengah peradaban yang lain. Kenyataan bahwa ada kelompok lain yang juga eksis, adalah suatu keniscayaan yang tidak mungkin terbantahkan. Persoalannya adalah bagaimana membangun sebuah peradaban dengan menjunjung semangat toleransi terbuka, dan adil. Sebagaimana dijelaskan oleh Nurcholish:

Membangun masyarakat yang berperadaban itulah yang Rasulullah SAW lakukan selama sepuluh tahun di Madinah. Beliau membangun masyarakat yang adi, terbuka, dan demokratis, dengan landasan takwa kepada Allah dan taat kepada ajaran-Nya. Takwa kepada Allah dalam arti semangat ketuhanan yang Maha Esa, yang dalam peristilahan kitab suci juga disebut semangat rabbaniyah atau ribbiyah. Inlah habl min Allah, tali

\footnotetext{
${ }^{37}$ Lihat Al-Quran dan terjemahannya.
} 
hubungan dengan Allah, dimensi vertikal hidup manusia, salah satu jaminan untuk manusia agar tidak jatuh hina dan nista. ${ }^{38}$

Gambaran sekilas diatas cukup untuk membuktikan bahwa asal-usul Islam itu sangat terbuka terhadap kelompok lain. Engineer menegaskan seperti yang dikutip oleh Agus Nuryatmo, Islam tidak hanya berarti suatu amal ibadah seperti sembahyang dan puasa, tapi juga merupakan dinamika kekuatan sosial dan budaya yang tidak bisa dipisahkan dari perhatiannya sehari-hari dengan persoalan masyarakat. Islam adalah sebuah proyek serius untuk menegakan keadilan sosial. ${ }^{39}$

\section{Tema-tema Pokok}

Dalam membangun dasar dari teologi inklusif, Cak Nur memetakan kata Islam menjadi dua. Pertama, islam dengan huruf (i) kecil, atau sering dikenal dengan islam umum. Kemudian yang kedua, Islam dengan huruf (I) besar, disebut juga dengan islam yang khusus. kata islam dalam pandangan Cak Nur merupakan bentuk mashdar (kata kerja benda yang menunjukan kegiatan) yang mempunyai arti "sikap pasrah kepada Allah.” Orang yang islam, artinya dia berserah diri kepada Allah SWT. ${ }^{40}$ Definisi Nurcholish madjid tentang islam dengan menggunakan huruf (i) kecil, searah dengan kandungan makna islam dalam pandangan Ibn Taimiyyah seperti yang dikutip dari buku Nurcholish:

Menurut Nurcholis, hakikat dari ajaran Islam adalah memiliki sifat ikhlas. Hal ini didasarkan bahwa kata al-Islam maknanya adalah menyerah pasrah (al-istislam) kepada Allah, dan tidak kepada yang lain. Oleh sebab itu, orang yang mengaku Islam tetapi ia tidak memiliki sikap menyerah dan pasrah, maka ia dikategorikan sebagai ombong. Terlebih bila ia mengaku menyerah pasrah kepada Allah tetapi juga menyerah pasrah kepada selain Allah, maka ia termasuk syirik. Sementara, sifat sombong dan syirik adalah kebalikan dari al-Islam.

${ }^{38}$ Nurcholish Madjid, Cita-cita Politik Islam (Jakarta : Paramadina, 1999), 108

${ }^{39}$ Agus Nuryatmo, Islam, Teologi Pembebasan dan Kesetaraan Gender (Jogjakarta : UII Press, 2001), 40-41

${ }^{40}$ Budhy Munawar Rachman, Enslikopedia Nurcholish Madjid, 1125 
Kata Islam memiliki bentuk lazim (yakni, tidak memerlukan penderita, intransitive), seperti firman Allah (untuk penggunaan perkataan Islam secara lazim) dalam Q.S. Al-Baqarah: 112. Oleh karena itu, pangkal alIslam ialah persaksian bahwa tiada Tuhan selain Allah, yang mencakup (pengertian) ibadah kepada Allah saja dan meninggalkan ibadah kepada yang lain. Inilah "Islam umum" (al-islam al amm) yang selain dari itu Allah tidak menerima sebagai agama dari umat terdahulu maupun umat kemudian. ${ }^{41}$

Definisi tersebut di atas sejalan dengan pengertian Islam yang diusung oleh Harun Nasution yang juga dikutip oleh Nurcholish bahwa Islam merupakan sikap diri yang menunjukkan kepasrahan, tunduk, patuh kepada Allah SWT. Sikap ini akan menimbulkan kedamaian, keselamatan, kesempurnaan hidup dan juga kesejahteraan dunia dan akhirat. ${ }^{42}$

Dalam Islam, kepatuhan berarti menunjukkan sikap kepasrahan kepada Tuhan secara total. Dengan begitu kepatuhan sejati hanya bisa dicapai dengan sikap pasrah atau islam. ${ }^{43}$ Seperti dalam penjelasan Cak Nur:

Inilah sesungguhanya makna firman Ilahi dalam QS. Al-Maidah: 19 yang amat banyak dikutip dalam berbagai kesempatan, Innadina indallahil Islam, sesungguhnya agama di sisi Allah ialah Islam. Bila diterjemahkan mengikuti makna asal kata-kata di situ, artinya menjadi "sesungguhnya kepatuhan bagi Allah ialah sikap pasrah (kepada-Nya)." Firman lain yang berkaitan langsung dengan ini, dan juga banyak dikutip, ialah QS. AlMaidah: 85, "dan barangsiapa mengikuti agama selain al-islam (sikap pasrah kepada Tuhan), maka ia tidak akan diterima, dan di akhirat ia akan termasuk golongan yang merugi." Ini adalah sebentuk penegasan bahwa beragama tanpa sikap pasrah itu tak bermakna. ${ }^{44}$

Untuk mencapai sikap pasrah kepada Allah harus muncul dari dalam diri manusia tersebut. Sikap ini tidak muncul dari paksaan, karena kalau dipaksakan akan menghilangkan nilai jati diri Islam sebagai agama

${ }^{41}$ Nurcholish Madjid, Islam Agama Kemanusiaan : Membangun Tradisi dan Visi Baru Islam Indonesia, xvi-xvii

${ }^{42}$ Muhaimin, Dimensi-dimensi 82.

${ }^{43}$ Nurcholish Madjid, Islam, Doktrin dan Peradaban, 41.

${ }^{44}$ Nurcholish Madjid, Islam, Doktrin dan Peradaban, 41-42 
yang memiliki nilai keikhlasan serta kemurniaan. Sikap yang timbul dari dalam diri manusia adalah fitrah. Islam yang bermakna pasrah kepada Tuhan merupakan lanjutan dari perjanjian antara manusia sebagai mahluk dan Tuhan. Maka dari itu, keislaman itu mutlak terletak dalam diri setiap individu. Hal ini dijelaskan oleh Nurcholish sebagai berikut:

Sikap-sikap tersebut di atas harus dijadikan landasan dalam memahami AlQur'an secara khusus. Dimulai dari memahami kata islam atau alislam dengan derivasinya seperti kata-kata muslim sebagai kata benda pelaku participle) atau kata sifat dari islam, dan seterusnya. Manusia, sebagai makhluk yang sempurna disbanding makhluk Allah lainnya, memiliki potensi dan kesadaran untuk untuk memilih apa yang diinginkannya. Manusia memiliki potensi "kebebasan" sebagai ciri manusia yanh sumbernya dari Ruh Tuhan. Untuk itu, kebebasan manusia adalah kebebasan terbatas, sebab kebebasan mutlak hanya ada pada Diri dan Wujud yang Mutlak pula, yaitu Allah, Tuhan Yang Maha Esa. Salah satu unsur keterbatasan manusia itu ialah bahwa bagaimanapun dan betapapun perkembangan dirinya, ia masih tetap harus tunduk dan pasrah kepada Tuhan (melakukan al-islam). Itu adalah natur (fithrah) manusia, yang dalam firman lain dilukiskan sebagai perjanjian (primordial) antara anak keturunan Adam dan Allah sendiri. Ketika manusia bersaksi bahwa tiada Tuhan selain Allah, maka artinya kesediaan untuk taat dan sukarela serta tunduk dan pasrah kepada-Nya, yaitu islam. Sebagai konsekuansi dari perjanjian primordial tersebut, maka manusia harus menjalankan makna dari term alislam tersebut. Hal ini sama halnya dengan ketundukkan alam (secara tidak sadar) mengikuti hukum-hukumnya sendiri yang sudah ditetapkan oleh Allah, Maha pencipta. Karena itu alislam bersifat alami, wajar, fithri dan natural. ${ }^{45}$

Dalam pandangan Cak Nur, sikap beragama yang benar adalah kepasrahan kepada Allah, seperti yang dijelaskan dalam Al-Quran Surat AlMaidah ayat $19 .{ }^{46}$ Maka dari itu kemudian Cak Nur berspekulasi bahwasannya islam dengan makna pasrah kepada Allah, ialah inti dari ajaran-ajaran para Nabi terdahulu.

\footnotetext{
${ }^{45}$ Nurcholish Madjid, Islam, Doktrin dan Peradaban, 428, 431-432.

${ }^{46}$ Budhy Munawar Rachman, Ensiklopedia Nurcholish Madjid, 1208
} 
Dengan demikian, sikap pasrah kepada Tuhan Yang Maha Esa merupakan ajaran dasar dari yang disebut sebagai agama (al-din, secara harfiah antara lain berarti ketundukan, kepatuhan atau ketaatan) yang dimaknai juga sebagai sikap pasrah kepada Tuhan (al-islam). Setiap orang yang beragama harus memiliki sikap kepasrahan kepada Tuhan yang merupakan keberagamaan yang sejati. Dari penjelasan tentang prinsipprinsip itu, maka semua agama yang benar pada hakikatnya adalah "alislam," yakni semuanya mengajarkan sikap pasrah kepada Sang Maha Pencipta, Tuhan Yang Maha Esa. Al-Qur'an juga berulang kali menegaskan bahwa agama para Nabi terdahulu sebelum Nabi Muhammad SAW, adalah semuanya "al-islam," karena ajaran dasar dari semua agama adalah ajaran tentang sikap pasrah kepada Tuhan. ${ }^{47}$

Sebagai contohnya adalah kata alislam yang terdapat dalam Q.S. AlMaidah: 19. Nurcholish menjelaskan bahwa maknanya adalah agama islam (agama yang dibawa dan diajarkan oleh Nabi Muhammad SAW). ${ }^{48}$ Selain itu islam juga dapat dipahami sesuai dengan makna awal, yakni suatu spirit ajaran yang menjadi inti semua agama yang benar. Kemudian pemahaman ini dalam pandangan Cak Nur, menjadi dasar pandangan bahwasannya semua agama yang benar ialah islam (sikap pasrah kepada Tuhan).

Inti dari Al-Islam sebagai din Allah, begitu juga dengan agama para Nabi terdahulu yaitu islam. Semua Para Nabi mengajarkan sikap tunduk dan pasrah kepada Tuhan. Hal ini dijlaskan oleh Nucholish sebagaimana dikutip oleh Budhy sebagai berikut:

Berdasarkan penjelasan dari pengertian kata al-islam di atas dan juga penegasan yang disebutkan dalam Al-Quran, bahwa semua agama para Nabi dan Rasul adalah agama Islam. Islam di sini diartikan sebagai agama yang mengajarkan sikap tunduk, patuh, pasrah dan berserah diri secara tulus kepada Tuhan dengan segala qodrat dan iradat-Nya. Contohnya, Nabi Ibrahim diceritakan sebagai seseorang yang tidak mengikuti agama komunal seperti Yahudi atau Nasrani. Tetapi ia digambarkan sebagai seseorang yang tulus mencari dan mengikuti kebenaran (hanif) dan yang

${ }^{47}$ Nurchlish Madjid, Islam, Doktrin dan Peradaban, 537

${ }^{48}$ Pengertian seperti itu, menurut Nurcholish tentu benar, dalam maknanya bahwa agama Muhammad adalah agama "pasrah kepada Tuhan" (islam) par excellence. Lihat Budhy Munawar Rachman, Ensiklopedia Nurcholish Madjid, 1207 
pasrah kepada Tuhan (muslim). Demikian agama, seluruh Nabi keturunan Ibrahim, khususnya anak-cucu Ya'qub atau Bani Israil juga menganut faham ini. Contoh lainnya adalah Nabi Musa yang dijelaskan dalam ucapan pertobatan Fir'aun bahwa Musa mengajarkan manusia untuk memeiliki sikap pasrah (muslim) kepada Tuhan. Dengan begitu, agama yang dibawanya bisa disebut sebagai agama Islam. Selain itu, sebuah ilustrasi tentang Nabi Isa dan para pengkutnya menunjukan bahwa agama yang diajarkannya pun adalah agama Islam, dalam arti agama yang mengajarkan sikap pasrah kepada-Nya. ${ }^{49}$

Agama disebut sebagai "perjanjian” (Mitsaq atau'ahd), dan intinya ialah tunduk kepada Allah. Ini merupakan perjanjian primordial manusia dengan Tuhan, yang terjadi sejak zaman azali. Semua para Nabi dan Rasul Allah itu, kemudian para pengikutnya yang setia, merupakan seorang Muslim (melaksanakan islam). ${ }^{50}$

Dalam pandangan Cak Nur, kata muslimun yang terdapat dalam AlQuran Surat Al-Ankabut ayat 46 dan Al-Maidah ayat 83-85 lebih merujuk kepada makna umumnya, yakni "orang-orang yang pasrah kepada Tuhan." Para pemeluk agama lain, khususnya penganut kitab suci dapat masuk kualifikasi perkataan muslimun ini, apabila meruntut pada makna generiknya. Pemikiran ini dikutip Cak Nur dari pandangan Ibn Katsir dan zamaksyari seperti yang dikemukakan oleh Budhy Munawar berikut:

Ibnu Katsir dalam tafsirannya tentang kata muslimun (mereka yang pasrah) mengatakan bahwa yang dimaksud ialah "mereka dari kalangan umat ini yang percaya kepada semua Nabi yang diutus, kepada semua kitab suci yang diturunkan, mereka tidak mengingkarinya sedikitpun, melainkan menerima kebenaran segala sesuatu yang diturunkan dari sisi Tuhan dan dengan semua Nabi yang dibangkitkan oleh Tuhan." Sedangkan AlZamakhsyari memberi makna kepada perkataan muslimun sebagai "mereka yang ber-tawhid dan mengikhlaskan diri kepada-Nya," dan mengartikan alislam sebagai sikap memahaesakan (ber-tawhid) dan sikap pasrah diri kepada Tuhan. Dari penafsiran tersebut dapat ditegaskan bahwa beragama tanpa sikap pasrah kepada Tuhan, betapapun seorang mengaku sebagai

\footnotetext{
${ }^{49}$ Budhy Munawar Rachman, Ensiklopedia Nurcholish Madjid, 1133-1136

${ }^{50}$ Nurcholish Madjid, Islam Agama Peradaban, 177-178
} 
"Muslim" atau penganut "Islam”, sebagai hal yang belum menunjukkan kepatuhan kepada Tuhan dan "tidak bakal diterima" oleh Tuhan. ${ }^{51}$

Ditugaskannya para Nabi merupakan sikap kasih Allah kepada manusia, karena walaupun secara fitrah manusia memiliki islam dalam dirinya, sepanjang perjalanan waktu ia bisa saja lupa. Maka dari itu diutusnya para Nabi oleh Allah SWT bertujuan untuk kembali kepada islam. Menurut Cak Nur, para Nabi dan Rasul yang diutus untuk umatnya masing-masing, pada hakikatnya membawa ajaran islam. Ajarannya tidak terbatas hanya pada agama samawi, lebih luas lagi bahkan menurut Cak Nur, ada indikasi bahwa Budha dan kong hu chu juga adalah Nabi. Indikasi ini Cak Nur terangkan seperti yang dikutip dari Budhy Munawar sebagai berikut:

Banyak diyakini bahwa Tuhan mengirim utusan kepada setiap umat, yang kadang disebut sebagai Nabi, Rasul atau maha guru. Al-Quran mengajarkan kita agar percaya kepada semua Nabi, sebagian Nabi diceritakan dalam Al-Quran dan sebagian lagi diceritakan dalam Bibel, tetapi banyak sekali yang tidak diceritakan dalam keduanya. Maka tidak mengherankan kalau Konghuchu dipandang sebagai Nabi oleh Hamka, atau Budha Gautama adalah Dzulkifli karena nama ini berarti orang yang berasal dari Kapilawastu (nama asal Budha). Memang selalu terbuka kemungkinan-kemungkinan dari nama-nama Nabi yang tidak disebutkan itu. $^{52}$

Meskipun demikian, Nurcholish menyebutkan bahwa di antara para Nabi dari garis keturunan Yaqub AS (kemudian melahirkan Yahudi) dan nabi Isa AS secara tegas Al-Quran menyebutkan bahwa mereka adalah islam. Ini mengindikasikan bahwasannya ajaran-ajaran mereka, juga adalah ajaran islam. Maka dari itu, agama Yahudi dan juga Nasrani, pada dasarnya merupakan islam. Kemudian ini yang membuat agama-agama bertemu pada titik yang sama, yaitu islam. Argumentasi tentang keislaman para Nabi ini dikemukakan oleh Cak Nur seperti berikut:

\footnotetext{
${ }^{51}$ Budhy Munawar Rachman, Ensiklopedia Nurcholish Madjid, 1207-1208

${ }^{52}$ Budhy Munawar Rachman , Ensiklopedia Nurcholish Madjid, 79
} 
Dijelaskan di dalam kitab suci bahwa Nabi yang pertama kali menyadari makna "al-islam" atau sikap pasrah kepada Tuhan itu sebagai inti agama ialah Nabi Nuh, Rasul Allah urutan ketiga dalam deretan dua puluh lima Rasul (seperti dipercayai umum), setelah Adam dan Idris. Di sini dijelaskan bahwa Nabi Nuh mendapat perintah Allah untuk menjadi salah seorang yang Muslim, yakni pelaku yang bersifat "al-islam", pasrah kepada Tuhan. Kesadaran akan "alislam" ini kemudian dikuatkan pada masa Nabi Ibrahim. Seperti halnya dengan Nuh, Ibrahim juga diperintah untuk ber"islam". Agama yang benar dengan inti ajaran pasrah kepada Tuhan itu kemudian diwasiatkan Ibrahim kepada keturunannya. Salah satu garis keturunan itu ialah Nabi Ya'qub atau Israil (hamba Allah) dari nasab Nabi Ishaq, salah seorang putra Ibrahim. Wasiat Ibrahim dan Ya'qub itu kemudian menjadi dasar agama-agama Israil, yaitu yang sampai sekarang bertahansebagai agama Yahudi dan Kristen. Jadi agama Yahudi dan Nasrani sebenarnya ajarannya berpangkal kepada "al-islam", karena merupakan kelanjutan agama Nabi Ibrahim. Namun demikian, ini tidaklah berarti bahwa Nabi Ibrahim adalah seorang Yahudi atau Nasrani, melainkan seorang yang pasrah kepada Tuhan (Muslim). Selain itu, masa hidup nabi Ibrahim jauh sebelum kedua agama itu muncul. Oleh karena "al-islam" merupakan titik temu semua ajaran yang benar. ${ }^{53}$

Dalam pandangan Nurcholish Madjid, walaupun pada hakikatnya semua agama adalah islam, tidak semua agama akan diterima oleh Allah. ini karena setiap penganut agama dituntut terus memperbaiki dirinya untuk lebih patuh, tunduk dan pasrah kepada Allah. ${ }^{54}$ Maka dari itu, ajaran islam yang dibawa Nabi Muhammad SAW adalah islam par excellence, sebagai penyempurna ajaran-ajaran terdahulu. Pengikut Nabi disebut muslim par excellence, yang berwawasan islam kosmopolis dan islam universal. Pendapat ini dikemukakan oleh Nurcholish seperti berikut:

Ajaran agama yang diserukan oleh nabi Muhammad disebut sebagai agama Islam. Hal ini karena beliau mengajarkan sikap pasrah kepada Tuhan, sehingga agama Nabi Muhammad merupakan islam par excellence. Namun demikian, agama Islam yang dibawa oleh Muhammad tidak hadir

\footnotetext{
${ }^{53}$ Nurcholish Madjid, Islam Doktrin dan Peradaba, $432-434$

${ }^{54}$ Budhy Munawar Rachman, Ensiklopdia Nurcholish Madid, 1133
} 
secara mandiri tetapi merupakan rangkaian dari ajaran sebelumnya yang juga mengajarkan tentang islam..$^{55}$

Jadi, "islam" memang telah menjadi nama sebuah agama, yaitu agama Rasul pungkasan. Terkandung dalam makna tersebut adalah sikap pasrah kepada Tuhan (alislam). Dengan begitu, maka seorang pengikut Nabi Muhammad adalah seorang Muslim par excellence, yang pada dasarnya tanpa mengekslusifkan yang lain, dalam menganut agamanya itu (seharusnya senantiasa sadar akan apa hakikat agamanya, yaitu "al-islam", selamanya mempunyai impulse universalisme, yang ada urutannya memancar dalam wawasan kulturalnya yang berwatak kosmopolit. ${ }^{56}$

Penjelasan Nurcholish bahwa Islam yang diturunkan kepada Nabi Muhammad merupakan islam yang menyempurnakan agama-agama sebelumnya, selaras dengan apa yang diungkapkan oleh Ibn Katsir. Nabi Muhammad SAW merupakan penutup semua jalan menuju Allah. Maka hanya ada satu syariat setelah diutusnya Nabi Muhammad, barang siapa yang menganut selain syariat Nabi Muhammad, maka Allah tidak akan menerima. ${ }^{57} \mathrm{Hal}$ ini sesuai dengan firman Allah SWT dalam Q.S Ali-Imran: 85:

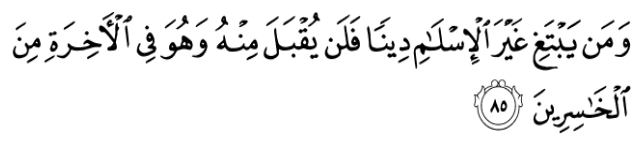

Barangsiapa mencari agama selain agama Islam, maka sekali-kai tidaklah akan diterima (agama itu) dari padanya, dan dia di akhirat termasuk orang-orang yang rugi. ${ }^{58}$

Menurut Quraish Shihab, Islam adalah agama para Nabi. Istilah muslimjuga dipergunakan untuk umat Nabi-nabi terdahulu, maka kemudian dikatakan bahwa islam merupakan sikap tunduk mahluk kepada Allah. Islam yang diajarkan Nabi-nabi terdahulu adalah sifat, sedangkan untuk

${ }^{55}$ Nurcholish Madjid, Islam Doktrin dan Peradaban, 427

${ }^{56}$ Nurcholish Madjid, Islam Doktrin dan Peradaban, 438-441

${ }^{57}$ M. Quraish Shihab, Membumikan Al-Quran : Fungsi dan Peran Wahyu dalam Kehidupan Masyarakat (Bandung : Mizan, 2007), 39

${ }^{58}$ Lihat Al-Qurab dan Terjemahannya. 
islam yang dibawa oleh Nabi Muhammad SAW, meneruskan sifat itu dan juga menjadi ciri serta nama untuknya. ${ }^{59}$

Maka dari itu Wifred Catwell seperti dijelaskan oleh Muhaimin, menyatakan bahwa begitu banyak tradisi agama di dunia ini, akan tetapi hanya tradisi islam yang akan tampak sebagai nama yang built-in. Kata islam tercantum di dalam kitab suci Al-Qur'an dan umat islam tetap teguh mepergunakannya sebagai pengenal keimanan mereka. Berbeda halnya dengan agama-agama yang lain. ${ }^{60}$

\section{Universalisme Islam}

Nurcholish Madjid berpandangan bahwa islam dalam arti sebagai agama mempunyai sifat universal. Derivasi keuniversalan islam ini melihat pada rahman dan Rahim Allah. Manifestasi dari sifat ini direalisasikan dalam bentuk tindakan berdasarkan maslahah dan manfaat dalam tataran sosiohistoris yang konkrit. Paradigm hidup universal menimbulkan penerimaan keterbukaan terhadap peradaban. ${ }^{61}$

Cak Nur berpandangan bahwa islam merupakan agama universal dengan keniscayaan yang luar biasa, hampir dekat dengan kemutlakan. Pendapat ini ia kemukakan sebagai berikut:

Meyakini bahwa Islam adalah agama universal hamper hampir sama dengan ungkapan bahwa bumi itu bulat. Terbelih di era kontemporer sekarang ini di mana orang banyak mengemukakannya untuk tujuan apologia maupun untuk pembahasan yang lebih sungguh-sungguh. ${ }^{62}$

Islam dalam kerangka universalisme adalah bahwa Islam dapat berlaku bagi siapapun di dunia ini. Dalam bahasa arab ada ungkapan alislam shalih pi kuli zaman wa makan. ${ }^{63}$ Islam universal merupakan ajaran yang mempunyai kemampuan untuk menyesuaikan dengan sosio-kultur sekitar.

${ }^{59}$ M. Quraish Shihab, Tafsir Al-Mishba: Peran, Kesan dan Keserasian Al-Quran (Jakarta: Lentera Hati, 2002), 38-39

${ }^{60}$ Muhaimin, dkk, Dimensi-dimensi, 71

${ }^{61}$ Ahmad Najib Burhani, Islam Dinami: Menggugat Peran Agama, Membongkar Doktrin yang membatu (Jakarta: Kompas, 2001), 71

${ }^{62}$ Nurcholish Madjid, Islam, Doktrin dan Peradaban, 425

${ }^{63}$ J. Suyuthi Pulungan, Universalisme Islam (Jakarta: Moyo Segoro Agung, 2002), 2 
Ini artinya islam universal mengutamakan nilai-nilai kemanusiaan dan juga keterbukaan. ${ }^{64}$

Dalam pandangan Nurcholish, islam universal bersifat fleksibel, maksudnya dari islam dapat kemana-mana, dan dari mana-mana dapat dibawa ke dalam islam. ${ }^{65}$ Dalam kamus filsafat, universal ialah tidak terikat ruang dan juga waktu. ${ }^{66}$ Cak Nur menambahkan bahwa islam universal merupakan ajaran bagi seluruh umat manusia di dunia, tidak melihat bahasa, tempat atau kelompok. Berikut adalah penjelasan Nurcholish Madjid:

Al-Quran menegaskan bahwa ajaran Islam ditujukan untuk seluruh umat manusia, karena Nabi Muhammad SAW adalah utusan Tuhan untuk seluruh umat manusia. Ini berarti ajaran Islam tidak hanya berlaku bagi bangsa Arab saja tetapi juga bagi bangsa-bangsa non-Arab dalam tingkat yang sama. Dan sebagai suatu agama universal, Islam tidak tergantung kepada suatu bahasa, tempat, ataupun masa dan kelompok manusia.$^{67}$

Keuniversalan Islam, bahwa Islam adalah agama yang berlaku untuk seluruh alam raya, didasarkan pada firman-firman Allah dalam Q.S. Saba: 28, dan Q.S. Al-Anbiya: 107. Dalam pandangan Nurcholish ini merupakan kesadaran umum dari kebanyakan umat muslim. Islam sebagai sikap tunduk pasrah kepada Tuhan merupakan bentuk wujud seluruh semesta. Menggunakan istilah lain, seluruh semesta raya merupakan suatu eksistensi ketundukan dan kepasrahan kepada Allah, baik dengan sendirinya ataupun dengan kesadaran sendiri. ${ }^{68}$

Universalime islam menimbulkan banyak pandangan. Apabila keuniversalan islam menyebabkan diutusnya para Nabi untuk setiap umat di waktu yang berbeda, maka artinya kebenaran juga ditemukan juga ada pada umat dan masa Nabi-nabi, sebagai suatu warisan dari utusan Allah. Dengan cara imilah kita dapat menangkap maksud Al-Qur'an bahwa

${ }^{64}$ MN. Ibad dan Akhmad Fikri AF, Bapak Tionghoa Indonesia (Jakarta: LKiS, 2012), 3 4

\footnotetext{
${ }^{65}$ Budhy Munawar Rachman, Ensiklopedia Nurcholish Madjid, 79

${ }^{66}$ Budhy Munawar Rachman, Ensiklopedia Nurcholish Madjid, 179

${ }^{67}$ Nurcholish Madjid, Islam, Doktrin dan Peradaban, 360

${ }^{68}$ Nurcholish Madjid, Islam Agama Peradaban, xiv
} 
diturunkannya Nabi dan Rasul untuk umatnya sangat penuh makna. Maka dari itu ini hendaknya mendorong kita untuk belajar dari bangsa manapun, sesuai dengan hadist nabi Muhammad SAW yang sering dikemukakan para ulama. ${ }^{69}$

Kepasrahan yang menjadi pondasi islam universal tidak bisa dipaksakan. Ia harus tumbuh dalam diri manusia itu sendiri. Maka dari itu, inilah yang menjadi dasar niversalisme islam. ${ }^{70}$ Seperti yang dikemukakan oleh Nurcholish Madjid:

Sumber inspirasi tentang universalisme Islam adalah dari kata islam itu sendiri. Sikap pasrah kepada Tuhan tidak saja merupakan ajaran Tuhan kepada hamba-Nya, tetapi ia diajarkan oleh-Nya dengan disangkutkan kepada alam manusia, sehingga pertumbuhan perwujudannya pada manusia selalu bersifat dari dalam, tidak tumbuh apalagi dipaksakan dari luar. Sikap keagamaan yang dihasilkan dari paksaan menjadi tidak autentik, karena kehilangan dimensinya yang paling mendasar dan mendalam, yaitu kemurnian atau keikhlasan. ${ }^{71}$

Islam universal, menurut Nurcholish merupakan salah satu kesadaran yang fundamental bagi seorang muslim, bahwa islam merupakan ajaran bagi seluruh manusia. Akan tetapi, menurut Cak Nur pemahaman semacam itu hanya sampai pada tataran teoritis saja. Umat islam belum sepenuhnya menyadari dampak dari pengaplikasian dari pemahaman universalisme islam. Pesan mendasar islam sebagai agama universal, pokokpokoknya adalah perjanjian dengan Tuhan, kepasrahan, dan kesadaran hadirnya Tuhan dalam kehidupannya. Tiga pokok itu sangat mendasar maka bersifat universal, berlaku bagi seluruh manusia. Cak Nur mengemukakan bahwa sebagai hukum dasar Allah, pesan itu melingkupi semesta alam, dimana manusia hanya setitik kecil dari semesta itu. ${ }^{72}$

Istilah Islam universal juga sering disebut dengan rahmatan lil alamin. Secara etimologi kata rahmat diambil dari bahasa Arab yakni kemanusian, kemuliaan, berbuat baik, menaruh pehatian, kemuliaan dan

\footnotetext{
${ }^{69}$ Nurcholish Madjid, Islam Agama Peradaban, xix

${ }^{70}$ Nurcholish Madjid, Islam Agama Peradaban, 438

${ }^{71}$ Nurcholish Madjid, Islam Agama Peradaban, 426

${ }^{72}$ Budhy Munawar Rachman, Ensiklopedia Nurcholish Madjid, xciv
} 
pengertian. Sedangkan kata alam artinya dunia, alam. ${ }^{73}$ Secara epistemologi, kata rahmatan diartikan nikmat, kesejahteraan, kemakmuran dan kasih sayang. Sedangkan alamin adalah segala sesuatu yang ada di langit dan bumi, yaitu mahluk Allah. Sebuah masyarakat dapat disebut sebagai masyarakat rahmah apabila terpenuhi kebutuhan jasmani dan rohani disertai terciptanya iklim kasih sayang. Masyarakat ini tidak terbatas pada luas batas, suku, ras, negara bahkan agama. ${ }^{74}$

Islam rahmatan li al-alamin diartikan dengan Islam yang mengemban misi terwujudnya kehidupan manusia yang penuh dengan kehangatan, saling pengertian, simpati, berbuat baik dan saling memuliakan. ${ }^{75}$ Islam sebagai agama rahmatan li al-alamin memiliki perspektif yang konstruktif terhadap perdamian dan kerukunan hidup. ${ }^{76}$ Islam rahmatan li al-alamin sering dihubungkan dengan misi kerasulan Nabi. Sebagaimana yang terdapat dalam firman Allah Q.S. Al-Anbiya: 107:

"Tiadalah Kami mengutus kamu, melainkan untuk (menjadi) rahmat bagi semesta alam."

Islam rahmatan li al-alamin dinilai sebagai Islam yang paling sesuai dengan keadaan masyarakat Indonesia yang plural. Melalui Islam rahmatan li al-alamin, diharapkan perbedaan agama, budaya, latar belakang etnis dan sebagainya tidak akan menimbulkan dampak negatif, atau tidak menjadi sumber konflik, melainkan sumber rahmat bagi seluruh alam. ${ }^{78}$ Islam rahmatan li al-alamin adalah agama Islam untuk kesejahteraan, kemakmuran, kasih sayang dan keadilanyang tercipta antara sesama mahluk di dunia. ${ }^{79}$

${ }^{73}$ Abudin Nata, Studi Islam Kontemporer, 528

${ }^{74}$ Tobroni Suyoto dan Muhammad Nurhakim, Misi Islam Rahmatan li al-alamin, dalam A.Faridi, Islam Kajian Interdisipliner (Malang : UMM Press, 1992), 4

${ }^{75}$ Abudin Nata, Studi Islam Kontemporer, 528

${ }^{76}$ Ruslani, Masyarakat Kitab dan Dialog antar Agama, Studi atas Pemikiran Muhammad Arkoun (Yogyakarta: Bentang, 2000), 8-9

${ }^{77}$ Lihat Al-Quran dan terjemahannya, 332

${ }^{78}$ Abudin Nata, Studi Islam Kontemporer, 528

79 Tobroni Suyoto dan Muhammad Nurhakim, Misi Islam Rahmatan li al-alamin, dalam A. Faridi, Islam Kajian Interdisipliner, 4 
Islam rahmatan li al-alamin tidak dapat terwujud dalam bentuk masyarakat atau corak hidup yang seragam. Islam rahmatan li al-alamin menghendaki umatnya untuk menjadi umatan wasathan, yaitu umat yang eksis dan menjadi poros di tengah-tengah pluralitas. Oleh sebab itu, ssetiap Muslim dituntut untuk mampu melaksanakan nilai-nilai Islam yang universal tersebut ke dalam berbagai konteks geografis, budaya, social, ekonomi, politik dan lain-lain. ${ }^{80}$

Istilah lain untuk term Islam rahmatan li al-alamin adalah Islam Inklusif. Kata Inklusif berasal dari bahasa Inggris, inclusive, yang berarti sampai dan termasuk. ${ }^{81}$ Inklusif perlu dibedakan dengan inklusifisme. Inklusif adalah sikap yang mengimani, menghayati dan mengamalkan ajaran agama yang dianutnya tanpa mengimani, membenarkan atau mengamalkan ajaran agama lain. Sedangkan inklusifime adalah sikap yang mengimani, menghayati mengamalkan atau menerima semua agama. Islam menerima adanya inklusifitas, tetapi menolak inklusifisme, karena dianggap sama dengan musyrik. ${ }^{82}$

Ayat-ayat Al-Quran telah mengajarkan untuk berpikir dan bersifat inklusif. Sikap inklusif ialah sikap mau merangkul semua pihak dan golongan dalam suatu tatanan kehidupan Islami. Ajaran Islam universal dalam kehidupan berbangsa dan bernegara dapat terwujud secara substansial apabila tidak menekankan simbol-simbol ritual dan tekstual. Sebab betapapun universalnya suatu ajaran, jika diberi label, akan berubah menjadi parsial dan ekslusif, yang justru akan mengaburkan makna universalitas itu sendiri. ${ }^{83}$

Setiap agama di dunia memiliki nilai ajaran dan doktrin khas masing-masing yang membedakan satu dengan lainnya sebagai nilai partikular. Namun demikina, setiap agama juga memiliki nilai umum yang dipercaya secara bersama oleh semua agama, yang disebut dengan nilai universal. Nilai partikular setiap agama, hanya diperuntukan bagi pemeluk agama itu sendiri dan tidak boleh dipaksakan kepada pemeluk agama lain.

\footnotetext{
${ }^{80}$ Tobroni Suyoto dan Muhammad Nurhakim, Misi Islam Rahmatan li al-alamin, dalam A. Faridi, Islam Kajian Interdisipliner, 10

${ }^{81}$ Abudin Nata, Studi Islam Kontemporer, 518

${ }^{82}$ Abudin Nata, Studi Islam Kontemporer, 121

${ }^{83}$ Hamka Haq, Islam: Rahmah untuk Bangsa (Jakarta: RMBook, 2009), 9-30
} 
Sementara nilai-nilai universal seperti keadilan, kemanusiaan, kesetaraan, berbuat baik kepada sesama, kejujuran dan sebagainya harus dikedepankan sebagai sikap toleransi antar pemeluk agama. ${ }^{84}$

Persamaan nilailah yang harusnya dikedepankan salah satunya adalah dari aspek sumber agama sebagai berasal dari Tuhan Yang Maha Esa. Semua Nabi dan Rasul membawa ajaran yang sama. Perbedaan yang ada hanyalah dalam bentuk perubahan pola perilaku (responsif) sesuai tuntutan zaman dan tempatnya di mana ajaran tersebut didakwahkan. Seyogyanya setiap perbedaan yang muncul tidak pada aspek prinsipil ajaran. ${ }^{85}$

Oleh sebab itu, masing-masing agama memiliki titik temu yang sama yang akan mengarahkan kepada kesadaran pluraslitik inklusif dan terbuka. Trauma-trauma yang terjadi di masa lalu akibat sejarah kelam pertikaian umat beragama harus dihilangkan demi masa depan keagamaan yang harmonis. Seperti yang diungkapkan Nurcholish Madjid yang dikutip oleh Budhy Munawar:

Agama Islam maupun Kristen pada dasarnya berasal dari jalur keluarga yang sama dan memiliki "titik temu" (menurut istilah Al-Quran, kalimat-un sawa), maka selalu diupayakan kemungkinan untuk "rekonsiliasi." Rekonsiliasi antara agama Yahudi, Kristen dan Islam pernah terjadi dalam satu fase sejarah semasa Islam berada dalam zaman keemasannya. Untuk mencapai rekonsiliasi tersebut perlu menumbuhkan sikap transendensi dari beban-beban sejarah, faktisitas sejarah dan traumatrauma masa lalu yang dapat membelenggu dan menghambat proyek masa depan. Hanya dengan cara ini, masa depan bisa dirancang secara lebih baik, dengan kesadaran pluralisme yang sekarang makin kita sadari tidak terelakan, yang harus kita letakan dalam kerangka ajaran keagamaan yang inklusif dan terbuka. ${ }^{86}$

Setiap agama diharapkan dapat menekankan pada perilaku universal sebagai landasan kepercayaan. Dan perilaku universal ini dapat digali dari ajaran masing-masing agama seperti Islam, Kristen, Yahudi,

84 M. Ainul Yaqin, Pendidikan Multikultural, Cross-Cultural Understanding untuk Demokrasi dan Keadilan (Yogyakarta: Pilar Media, 2005), xiv

${ }^{85}$ Nurcholish Madjid, Islam Agama Kemanusiaan, 142

${ }^{86}$ Budhy Munawar Rachman, Ensiklopedia Nurcholish Madjid, 2865 
Hindu dan lainnya. Nilai-nilai kebaikan bagi sesama bisa dijadikan awal dari nilai universal tersebut. Harapan dalam agama Yahudi, kedermawanan dalam agama Kristen, dan keimanan dalam agama Islam juga merupakan bentuk dasar dari perilaku baik.

\section{Simpulan}

Dari pemaparan di atas berkaitan dengan teologi inklusif Nurcholis Madjid dapat dibedakan menjadi dua bagian:

1. Argumen dasar dari pemikiran teologi inklusif Nurcholis Madjid.

Teologi inklusif yang diformulasikan oleh Nurcholish Madjid bersandar pada kenyataan bahwa kemajemukan umat manusia adalah suatu yang niscaya, dan itu merupakan pesan Allah yang tertulis dalam Al-Quran. Ayat tersebut mampu mendorong lahirnya sikap pluralisme, yaitu sebuah sistem nilai yang secara positif optimis terhadap pluralitas itu dengan menerimanya sebagai kenyataan dan menebarkan kebaikan. Tuhan tidak mendriskriminasi, Dia akan selalu berlaku objektif dan tidak pernah memihak kecuali hanya kepada kebenaran. Maka sudah seharusnya manusia bersikap terbuka, menerima segala kebenaran dari siapapun. Nurcholish menegaskan bahwa sikap sadar diri adalah kunci untuk mengenal Tuhan. Dengan kata lain seseorang akan sadar akan keterbatasan dirinya dan sepenuhnya meyakini bahwa hanya Tuhanlah yang mutlak dan yang paling sempurna.

2. Rancang bangun pemikiran teologi inklusif Nurcholish Madjid.

Al-Quran dan sejarah Nabi Muhammad SAW menjadi sumber inspirasi dari bangunan teologi inklusif Nurcholish Madjid. Menurut Cak Nur, peradaban Madinah era Nabi Muhammad SAW layak menjadi sumber inspirasi kehidupan Muslim. Karena Islam dalam ajarannya sesungguhnya sangat menjunjung tinggi keterbukaan, keadilan, demokrasi dan perdamaian. Pada saat itu, Madinah ditempati berbagai kelompok manusia yang berbeda-beda. Akan tetapi, dengan kebijaksaan Nabi dengan dibuatnya piagam Madinah, semua kelompok diakui keberadaannya dan mampu hidup dalam perdamaian tanpa mempersoalkan agama apa yang dianutnya. Karena adanya titik persamaan antara kelompok yang ada, dan akhirnya mampu membangun peradaban yang harmonis dan saling menghargai. 
Islam menurut Nurcholish Madjid adalah agama universal, berlaku bagi seluruh umat manusia. Istilah Islam universal juga diistilahkan dengan rahmatan lil al amin, yang mengemban misi terwujudnya kehidupan manusia yang penuh dengan kehangatan, saling pengertian, simpati, berbuat baik dan saling memuliakan. Istilah ini menjadi konstruk terhadap kerukunan dan perdamaian hidup. 


\section{DAFTAR PUSTAKA}

Abbas, Zainal Arifin. Perkembangan Pikiran Terhadap Agama. Jakarta: Pustaka Al-Husna, 1984.

Abdullah, Amin. "Tinjauan Antropologis-Fenomenologis Keberagamaan Manusia: Sumbangan Pendekatan Filsafat untuk Studi Agama," dalam Agama dan Masyarakat, Abdurahman, Burhanudin Daya, Djam'annuri (ed). Yogyakarta: IAIN Sunan Kalijaga, 1993. . Falsafah Kalam di Era Postmodernisme. Yogyakarta: Pustaka Pelajar, 2016. . Dinamika Islam Kultural, Pemetaan Atas Wacana Keislaman

Kontemporer. Jakarta: Mizan, 2001.

Ali, Fachry. Agama, Islam dan Pembangunan. Jakarta: Pusat Latihan, Penelitian dan Pengembangan Masyarakat, 1985.

Arif, Mahmud. "Pendidikan Agama Islam yang Inklusif-Multikultural dalam Bingkai

Keislaman dan Keindonesiaan,” Jurnal Al-Fikr, Vol. 15, No. 2 (2011).

Arnis, Adnan. "Gagasan Frithjof Schuon Tentang Titik Temu Agamaagama", Islamia, Vol 1, No.3 (2004).

Asikin, Amirudin Zainal. Pengantar Metode Penelitian Hukum. Jakarta: Raja Grafindo Persada, 2006.

Baharuddin, M. Pembaharuan Pemikiran Islam di Indonesia. Bandar Lampung: Harakindo Publishing, 2009.

Bakar, Osman. Tauhid dan Sains. Bandung: Pustaka Hidayah, 2008.

Banawiratma, J.B. "Pandangan Keagamaan Membantu atau Mengganggu", dalam Abdurahman, Burhanuddin Daya, Djam'annuri (ed), Agama dan Masyarakat. Yogyakarta: IAIN Sunan Kalijaga, 1993.

Barton, Greg. Gagasan Islam Liberal di Indonesia. Jakarta: Paramadina, 1999. Burhani, Ahmad Najib. Islam Dinamis: Menggugat Peran Agama, Membongkar Doktrin yang membatu. Jakarta: Kompas, 2001.

Coward, Harold. Pluralisme: Tantangan bagi Agama-agama. Yogyakarta: Kanisius, 1994.

Dister, Nico Syukur. Pengalaman dan Motivasi Beragama. Yogyakarta: Kanisius, 2000.

Faridi, A. Islam Kajian Interdisipliner. Malang: UMM Press, 1992.

Hanafi, Hasan. Agama, Ideologi dan Pembangunan, Ter. Shonhaji Shaleh. Jakarta : P3M, 1991.

. Dialog Agama dan Revolusi. Jakarta: Pustaka Firdaus, 1994.

Hanafi, Ahmad. Pengantar Teologi Islam. Jakarta: PT Pustaka al-Husna, 2003. 
. Teologi Islam: Ilmu Kalam. Jakarta: PT Bulan Bintang, 2010.

Hatta, Muhammad. Alam Pikiran Yunani. Jakarta: Tintamas, 1986.

Hidayat, Khomarudin. dan Ahmad Gaus AF. Passing Over, Melintasi Batas Agama. Jakarta : PT.Gramedia Pustaka Utama bekerja sama dengan Paramadina, 1998. . Tragedi Raja Midas. Jakarta: Paramadina, 2000. dan Wahyuni Nafis, Agama Masa Depan: Perspektif

Filsafat Perennial. Jakarta : Grafindo Pustaka Utama, 2003.

Hukley, Aldous. Filsafat Perennial. Yogyakarta : Qalam, 2001.

Humas Kemenag, "UU hanya akui 6 agama, kemenag: pemeluk agama lain tetap bisa jalankanibadahnya,"2013, diakses pada 2 Februari 2018 pukul 20.53 wib, http:/ www.kemendagri.go.id/ news/2013/11/28/ uuhanya-akui-6-agama- kemenag-pemeluk-agama-lain-tetap-bisajalankan-ibadahnya.

http://mifthachoelamien.blogspot.com/2014/01/vbehaviorurldefaultvmlo. html, diakses pada minggu, 15 Juli 2018 pukul $22.17 \mathrm{Wib}$

http://mifthachoelamien.blogspot.com/2014/01/vbehaviorurldefaultvmlo. html, diakses pada jumat 13 Juli 2018 pukul 20.00 wib.

Ibad, MN., dan Akhmad Fikri AF. Bapak Tionghoa Indonesia. Jakarta: LKiS, 2012.

Idrus, Junaidi. Rekonstruksi Pemikiran Nurcholish Madjid: Membangun Visi dan Misi Baru Islam Indonesia. Yogyakarta: Logung Pustaka, 2004.

Imawan, Sukidi. Teologi Inklusif Cak Nur. Jakarta: Kompas, 2011.

Jaspers, Karl. The Perennial Scope of Philosophy. London: Routledge \& Kegan Paul Ltd, 1950.

Kurzman, Charles. Wacana Islam Liberal. Jakarta: Paramadina, 2001.

Kuswanjono, Arqom. Ketuhanan dalam Telaah Filsafat Perenial: Refleksi Oluralisme di Indonesia. Yogyakarta: Badan Penerbitan Filsafat UGM, 2006.

Leaman, Oliver. Pengantar Filsafat Islam, Sebuah Pendekatan Tematis. Bandung:

Mizan,1999.

Lee, Robert. Islam Otentik dari Nalar Muhammad Iqbal sampai Nalar Muhammad Arkoun. Bandung: Mizan, 1999.

Madjid, Nurcholish. Islam, Kemodernan dan Keindonesiaan. Bandung : Mizan, 2013. . Islam, Doktrin dan Peradaban: Sebuah Telaah Kritis tentang

Masalah Keimanan dan Kemodernan. Jakarta: Paramadina, 2005. . Pintu-pintu Menuju Tuhan. Jakarta: Paramadina, 1994. 
1984.

- Khazanah Intelektual Islam. Jakarta: Bulan Bintang,

Relevansi Islam

- Islam Agama Peradaban Membangun Makna dan

dalam Sejarah. Jakarta: Paramadina, 1995.

sosial

. Dialog Keterbukaan: Artikulasi Nilai Islam dalam Wacana

Politik Kontemporer. Jakarta: Paramadina, 1999.

. Islam Agama Kemanusiaan: Membangun Tradisi dan Visi

Baru

Islam Indonesia. Jakarta: Paramadina, 1995.

Cita-cita Politik Islam Era Reformasi. Jakarta:

Paramadina, 1999.

Martin, Richard. C. Pendekatan Kajian Islam dalam Studi Agama, terj.

Zakiyuddin Bhaidawy.Solo: Universitas Muhammadiyah Surakata UMS, 2001.

Maulana, Abdullah Muslich Rizal. "Kesatuan Transenden Agama-agama dalam Perspektif Tasawuf: Kritik atas Pemikiran Fritjhof Schuon," Kalimah, Vol 12, No 2 (2014) : Hal 204.

Misrawi, Zuhairi. Madinah: Kota Suci, Piagam Madinah dan Teladan Muhammad SAW Jakarta: PT Kompas Media Nusantara, 2009.

Muhaimin, Dimensi-dimensiStudi Islam. Surabaya: Karya Abditama, 1994.

Nasr, Seyyed Hossein. Pengetahuan dan Kesucian (knowledge and the Secred), terj.

SuharsonoYogyakarta: Pustaka Pelajar, 1997.

Nasution, Harun. Teologi Islam : Aliran-aliran Sejarah Analisa Perbandingan. Jakarta : UI-Press, 2013.

. Islam di Tinjau dari Beberapa Aspek. Jakarta: UI Press, 1985. Islam Rasional: Gagasan dan pemikiran. Bandung: Mizan, 1995.

Nata, Abuddin. Ilmu Kalam, Filsafat dan Tasawuf. Jakarta: Raja Grafindo Persada, 1998.

Nuryatmo, Agus. Islam, Teologi Pembebasan dan Kesetaraan Gender Jogjakarta: UII Press, 2001.

Nurhadi, Rofiq, Syamsul Hadi, Thoyib I.M dan Suhandano, "Dialektika Inklusivisme Islam Kajian semantic Terhadap Tafsir Al-Quran Tentang Hubungan Antaragama," Kawistara, Vol 3, No. 1 (2013): Hal 59.

Permata, Ahmad Norma. Perennialisme Melacak Jejak Filsafat Abad. Yogyakarta: PT Tiara Wacana Yogya, 1996. 
Pulungan, J.Suyuthi. Universalisme Islam. Jakarta: Moyo Segoro Agung, 2002.

Rachman, Budhy Munawwar dan Elza Peldi Taher, Satu Menit Pencerahan Nurcholish Madjid.Depok: Paramadina, 2013.

Democracy Project, 2010.

Membaca Nurcholish Madjid. Jakarta:

Rahman, Fazlur. Islam : Sejarah Pemikiran dan Peradaban. Bandung: Mizan, 2017.

Rabi, Ibrahim M. Abu. Intellectual Origins of Islamic Resurgence in the Modern Arab. Albany : State University of New York Press, 1996.

Riyanto, Adi. Metodologi Penelitian Sosial dan Hukum. Jakarta: Granit, 2004.

Ruslani, Masyarakat Kitab dan Dialog antar Agama, Studi atas Pemikiran Muhammad Arkoun. Yogyakarta: Bentang, 2000.

Sabri, M. Keberagamaan yang Saling Menyap: Perspektif Filsafat Perenial. Yogyakarta: Adipura, 1999.

Schmitt, Charles B., (dkk). Perennialisme Melacak Jejak Flsafat Abadi. Yogyakarta: PT Tiara Wacana Yogya, 1996.

Schuon, Frithjof. Islam dan Filsafat Perennial, Terj. Rahmani Astuti. Bandung: Mizan, 1993.

Shihab, M. Quraish. Membumikan Al-Quran: Fungsi dan Peran Wahyu dalam Kehidupan Masyarakat. Bandung: Mizan, 2007. . Tafsir Al-Mishbah: Peran, Kesan dan Keserasian Al-Quran.

Jakarta: Lentera Hati, 2002.

Shihab, Alwi. Islam Inklusif: Menuju Sikap terbuka dalam beragama. Jakarta: Mizan, 1997.

Sugiharto, Bambang., (dkk). "Relasi Pengetahuan Islam Eksoteris dan Esoteris”, Teosofi, Vol 2, No. 2 (2012): Hal 336.

Tafsir, Ahmad. Filsafat Umum: Akal dan Hati Sejak Thales sampai Capra. Bandung : Remaja Rosdakarya, 1990.

Umar, Nasaruddin. Deradikalisasi Pemahaman Al Quran dan Hadis. Jakarta: PT Elex Media Komputindo Kompas Gramedia, 2014.

Wahib, Ahmad. Pergolakan Pemikiran Islam. Jakarta : Democracy Project, 2012.

Wasim, Alef Theria. Harmonisasi Kehidupan Beragama : Problem, Praktik dan Yaqin, M. Ainul. Pendidikan Multikultural, Cross-Cultural Understanding untuk Demokrasi dan Keadilan. Yogyakarta : Pilar Media, 2005.

Zahrah, Imam Muhammd Abu.Aliran Politik dan Akidah dalam Islam, terj. Abd Rahman Dahlan dan Ahmad Qarib. Jakarta : Logos Publishing House, 1996. 